\title{
Media and Book Reviews
}

Section Editor

Mitchell S.V. Elkind,

MD, MS

Daniel M. Goldenholz, $\mathrm{MD}, \mathrm{PhD}$

Address correspondence and reprint requests to Dr. Daniel Goldenholz, Department of Neurology, UC Davis Medical Center, 4860 Y Street, Suite 3700, Sacramento, CA 95817 Goldenholz@alum.bu.edu

\section{MEDICATIONS: HOW CAN WE KNOW THEM} ALL?

When are you planning to study all the important details of the more than 20 new drugs that get approved each year by the Food and Drug Administration (FDA)? Similarly, what about the hundreds of labels, interactions, and side effect profiles that are constantly being updated? Likely, the answer is never. Yet a major component of clinical practice relates to drugs and the ever-changing details about them. Many have turned to mobile applications for smartphones, tablets, and PDAs for updates on the go.

I selected 4 common apps, all of which are free and available on multiple mobile platforms (all are available for Apple, Blackberry, and Android platforms; Medscape is not available for Palm or Windows Mobile). I tested these apps on the Apple iPad and iPhone. All 4 allow automatic updating without special steps by the user. All 4 provide detailed monographs on thousands of drugs, including indications, dosing, adverse effects, pharmacology, and more.

If you want the bottom line without getting into the details, I recommend getting all 4 apps. Each has different strengths and weaknesses, and until the ideal app that combines all strengths is developed, you will benefit from having all 4 apps and knowing when to use them (table).

Medscape. This app was king among those reviewed. Drawing from the same massive database as the Medscape website, it brings drug and herbal medication information, interactions, diseases, procedures, news, and CME to one extremely well-thought-out mobile portal. It looks great on the iPad, but it is very nice on the iPhone too. Think of this app as a multivolume, continually updated textbook. Articles are well-written and peer-reviewed. One has the option to download the entire article collection (more than $10,000)$ in case consistent Internet access is not avail- able. Missing from this app are pill photos and the ability to search by drug class.

mobileMicromedex. This app came out just a few months ago and is based on the high-quality online Micromedex product, typically purchased by institutions and widely used by pharmacists. Each drug includes a tab for "Clinical Teaching," which summarizes the counseling that should be provided to patients. Additionally, the adverse effects section is nicely organized by system and includes percentages of patients affected. The mechanism of action is more complete and helpful here than in other apps. mobileMicromedex has a unique toxicology tab that reviews ranges, effects, and treatments for toxic doses. Thomson Reuters released a separate paid (except to subscribed institutions) app that checks for drug interactions, but I found this cumbersome because it is not directly connected to the principal app. The online product is superb and superior to the app. The Web site suggests using a mobile Web browser to connect to the enhanced portal, but the interface is clearly not designed for mobile devices. There are several helpful features that are available on the Web but not yet in the app, including pill pictures, pill identifier, drug comparisons, calculators, and patient education information.

Epocrates. According to their Web site, roughly 45\% of US physicians currently use this app. This is likely because Epocrates has been around the longest and offers a great deal of detailed, trusted drug information for free. An annual subscription fee gains you access to a wider set of tools that includes a disease database, infectious disease guide, alternative medicine information, and a medical dictionary. Even without the fee you get a solid app that includes a drug identification tool searchable by color, shape, and imprint. The images of pills at every available strength are handy when patients do not know their medications well. Access to the pill pictures requires either Wi-Fi or cellular data connection, so poor net- 


\begin{tabular}{|c|c|c|c|c|}
\hline Table & Four apps & & & \\
\hline & Medscape & mobileMicromedex & Epocrates & mobilePDR \\
\hline Pros & $\begin{array}{l}\text { Comprehensive, disease } \\
\text { articles, best interface }\end{array}$ & $\begin{array}{l}\text { Detailed drug information, } \\
\text { integrated toxicology, } \\
\text { clinical teaching tab }\end{array}$ & $\begin{array}{l}\text { Pill identification and } \\
\text { pictures, formulary } \\
\text { integration }\end{array}$ & $\begin{array}{l}\text { Outstanding drug monographs, } \\
\text { trusted PDR resource, clinical } \\
\text { studies tab }\end{array}$ \\
\hline Cons & $\begin{array}{l}\text { No pill pictures, mechanism } \\
\text { of action less detailed, no } \\
\text { search by drug class }\end{array}$ & $\begin{array}{l}\text { Lacking some of the online } \\
\text { features, cumbersome } \\
\text { interaction checker (not } \\
\text { free) }\end{array}$ & $\begin{array}{l}\text { No iPad version, costly } \\
\text { extras, adverse effects } \\
\text { often without } \\
\text { percentages, less } \\
\text { detailed mechanism of } \\
\text { action, drug-sponsored } \\
\text { advertisements }\end{array}$ & $\begin{array}{l}\text { Clunky interface, some drugs } \\
\text { and pictures not included, } \\
\text { medical license required, no } \\
\text { interaction checker, no search } \\
\text { by class }\end{array}$ \\
\hline
\end{tabular}

work reception in your hospital means you can forget this feature. Epocrates exclusively offers a formulary integration system that immediately informs you if a drug is covered or not at your institution. Other helpful features include an integrated interaction checker, several clinical calculators, and certain drug company-sponsored clinical summaries. An iPad version of the app is planned (unspecified future date). One less attractive feature of the Epocrates app was the arbitrary listing of adverse effects that was alphabetical for some drugs and "common" vs "uncommon" for others. Another concern of mine was the frequent alerts billed as helpful updates about various drugs; these updates were often sponsored by drug companies.

mobilePDR. This less well-known app comes from the ubiquitous Physician's Desk Reference and is free for licensed physicians and fee-only for others. Four phone calls to tech support finally had the app up and running for me in both of its 2 forms (standalone app and embedded book in Skyscape, the latter of which permits control over font size). The interface is not as user-friendly as those of other apps. While some common drugs are not listed at all (e.g., Advil), the included drugs have amazingly detailed monographs that are referenced and describe the studies behind the statements. Some drugs include a specific tab on clinical studies for that drug. Some drugs include pill pictures. The comprehensiveness of the drug monographs in mobilePDR surpasses all other apps reviewed here.

Disclosure: Dr. Goldenholz serves on the editorial team for the Neurology ${ }^{\circledR}$ Resident \& Fellow Section.

Copyright (C) 2011 by AAN Enterprises, Inc.

Note to Book Publishers: Neurology ${ }^{\circledR}$ provides reviews of books of interest to the clinical neurologist. Please send any books for possible review in the journal to: Robert A. Gross, MD, PhD, FAAN, Editor-in-Chief, Neurology, 1080 Montreal Ave, St. Paul, MN 55116. Inquiries can be directed to: Journal@neurology.org. Please note that not all books received are chosen for review. We do not return books. 


\section{Neurology}

\section{Media and Book Reviews: Medications: How can we know them all? \\ Daniel M. Goldenholz \\ Neurology 2011;77; e143-e144 \\ DOI 10.1212/WNL.0b013e31823d76ca}

This information is current as of December 12, 2011

\section{Updated Information \&}

Services

Permissions \& Licensing

Reprints including high resolution figures, can be found at: http://n.neurology.org/content/77/24/e143.full

Information about reproducing this article in parts (figures,tables) or in its entirety can be found online at:

http://www.neurology.org/about/about_the_journal\#permissions

Information about ordering reprints can be found online:

http://n.neurology.org/subscribers/advertise

Neurology ${ }^{\circledR}$ is the official journal of the American Academy of Neurology. Published continuously since 1951, it is now a weekly with 48 issues per year. Copyright Copyright $@ 2011$ by AAN Enterprises, Inc.. All rights reserved. Print ISSN: 0028-3878. Online ISSN: 1526-632X.

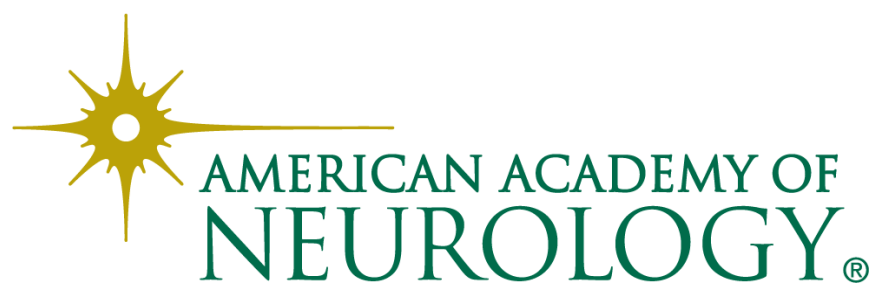

